LA W RENCE LIVERMORE NATIONAL LABORATORY

\section{GAMA-LLNL Alpine Basin Special Study: Scope of Work}

M. J. Singleton, A. Visser, B. K. Esser, J. E. Moran

December 13, 2011 
This document was prepared as an account of work sponsored by an agency of the United States government. Neither the United States government nor Lawrence Livermore National Security, LLC, nor any of their employees makes any warranty, expressed or implied, or assumes any legal liability or responsibility for the accuracy, completeness, or usefulness of any information, apparatus, product, or process disclosed, or represents that its use would not infringe privately owned rights. Reference herein to any specific commercial product, process, or service by trade name, trademark, manufacturer, or otherwise does not necessarily constitute or imply its endorsement, recommendation, or favoring by the United States government or Lawrence Livermore National Security, LLC. The views and opinions of authors expressed herein do not necessarily state or reflect those of the United States government or Lawrence Livermore National Security, LLC, and shall not be used for advertising or product endorsement purposes.

This work performed under the auspices of the U.S. Department of Energy by Lawrence Livermore National Laboratory under Contract DE-AC52-07NA27344. 


\section{Scope of Work}

\section{GAMA Special Study: Climate Change Impacts to Recharge and Groundwater Quality in High- Elevation Basins}

\section{GENERAL SCOPE OF WORK}

For this task LLNL will examine the vulnerability of drinking water supplies in foothills and higher elevation areas to climate change impacts on recharge. Recharge locations and vulnerability will be determined through examination of groundwater ages and noble gas recharge temperatures in high elevation basins. LLNL will determine whether short residence times are common in one or more subalpine basin. LLNL will measure groundwater ages, recharge temperatures, hydrogen and oxygen isotopes, major anions and carbon isotope compositions on up to 60 samples from monitoring wells and production wells in these basins. In addition, a small number of carbon isotope analyses will be performed on surface water samples.

\section{DELIVERABLES}

The deliverable for this task will be a technical report that provides the measured data and an interpretation of the data from one or more subalpine basins. Data interpretation will,

- Consider climate change impacts to recharge and its impact on water quality;

- Determine primary recharge locations and their vulnerability to climate change; and

- Delineate the most vulnerable areas and describe the likely impacts to recharge.

Draft Technical Report: February 28, 2013

Final Technical Report: April 30, 2013

\section{FUNDING}

The proposed LLNL study in Martis Valley is fully funded by the Groundwater Ambient Monitoring \& Assessment Special Studies Program.

About State of California GAMA Special Studies: http://www.swrcb.ca.gov/gama/special_studies.shtml

In January 2002, Assembly Bill 599 (AB 599) established the Groundwater Quality Monitoring Act of 2001 and amended Sections 10780-10782.3 of the Water Code to require that the State Water 
Board establish a statewide comprehensive groundwater quality monitoring program. In response, the State Water Board has developed a plan for implementing a program to comprehensively monitor and assess the quality of all groundwater basins in the State.

The Groundwater Ambient Monitoring \& Assessment (GAMA) Program is detailed in the AB599 Report to the Governor and Legislature entitled "A Comprehensive Groundwater Quality Monitoring Program for California", released by Governor Davis in November 2003. The GAMA Program currently includes the Priority Basin Project, Domestic Well Project, and Special Studies Project. A major goal of the GAMA Program is to increase the availability of information about groundwater quality to the public.

The GAMA Special Studies Project provides analysis and interpretation of constituents of concern, as described in the AB 599 Report, which will allow assessment of current groundwater conditions. In addition, the GAMA Special Studies Project includes analyses that will enhance the monitoring and assessment effort by focusing on specific constituents of concern and water quality parameters, such as waste water indicators, emerging contaminants and nitrate. Lawrence Livermore National Laboratory (LLNL) designs and carries out these Special Studies in coordination with the State Water Board.

\section{COLLABORATION, DATA SHARING, AND PRIVACY CONCERNS}

LLNL will be collaborating with Matt Reeves and Justin Huntington of DRI by providing isotopic data and analysis that will support their modelling efforts. LLNL will share any data collected with landowners, water agencies and other stakeholders involved in the development of the Martis Valley Groundwater Management Plan (GMP), as these data may lead to an increased understanding of recharge processes in the basin. To that end, we will make our draft and final technical reports available to interested parties.

LLNL will follow strict protocols on the public release of data in order to protect the release of senstive information on the location of private and public supply wells. Wells will be given generic names in our reports that do not correspond to their actual names, and we will not publish detailed coordinate locations for the public and private supply wells in our report. Additional privacy concerns will be addressed as they arise.

\section{Well SELECTiON}

The selection of specific wells for this study is under way. Currently, we are considering the area of the Martis Valley Basin that lies roughly south of Interstate 80 and east of Highway 89. LLNL is coordinating with Matt Reeves (DRI) and Chris Bonds (DWR) in the search for appropriate wells for our study. We are also planning to coordinate with participating water agencies in the selection of wells.

Approximately 30 wells are needed for this study, and these wells will likely include both production wells and monitoring wells. We hope to identify wells over a range of elevations within 
the study area, and with a range of screen depths (approximately 800 feet bgs to the surface). Ideal wells for this study would have the following qualities:

- Known screened interval and depth

- 2-inch diameter or larger

- Easily accessible

- Known pumping rates and history (production wells)

- Documented logs of lithology

- Short screened intervals of less than 20 feet (monitoring wells)

\section{SAMPling MethodS}

LLNL will collect samples from monitoring wells using a portable submersible pump. LLNL will bring all sampling equipment and supplies to each sampling site. Sample collection volume will be less than two liters, but a much larger quantity of water (equivalent to 2 well casing volumes) may be pumped in order to purge the well. Samples from running production wells will be collected from a tap located upstream of any treatment systems or pressure tanks.

\section{WELL ACCESS NEEDS}

Approximately 30 wells will be selected for sampling during the period of this study (Fall 2011Spring 2013). The majority of these wells (approximately 20-25) will be visited only once during the study period. A small subset of 5-10 wells will be visited 3-4 times in order to document seasonal changes in recharge sources and groundwater flow. LLNL will require the support of wellowners in providing access to wells that are on private property, locked, or located within enclosed structures.

\section{DESCRIPTION OF ANALYSES TO BE PERFORMED ON GROUNDWATER SAMPLES}

Our study aims to delineate recharge sources and processes by measuring the isotopic compositions of a variety of natural tracers present in the environment. By understanding groundwater residence times and the location of important recharge areas, it will be possible to better determine the vulnerability of groundwater supplies to potential changes in climate. An enhanced understanding of groundwater flow paths and recharge areas will also allow for a better understanding of the processes that could affect groundwater quality. However, the measurement regulated (Title 22) compounds (such as VOC's nutrients, etc.) related to groundwater quality is not part of the LLNL study.

The following list of analytes are being considered for this study. The final analytes selected for the study may not include all of those listed. The value of these tracers for understanding recharge processes and groundwater flow has been shown in numerous studies by LLNL and other researchers. The Appendix gives additional background and description of these potential environmental tracers and their benefit to this study. 
- Dissolved noble gases $\left({ }^{3} \mathrm{He} /{ }^{4} \mathrm{He}, \mathrm{He}, \mathrm{Ne}, \mathrm{Ar}, \mathrm{Kr}, \mathrm{Xe}\right)$

- $\quad$ Tritium $\left({ }^{3} \mathrm{H}\right)$

- Stable isotopes in water and dissolved inorganic carbon $\left({ }^{2} \mathrm{H} /{ }^{1} \mathrm{H},{ }^{18} \mathrm{O} /{ }^{16} \mathrm{O},{ }^{13} \mathrm{C} /{ }^{12} \mathrm{C}\right)$

- Sulfur isotopes $\left({ }^{35} \mathrm{~S},{ }^{34} \mathrm{~S},{ }^{32} \mathrm{~S}\right)$

- $\quad$ CFC's and $\mathrm{SF}_{6}$

- $\quad 222 \mathrm{Rn}$

- Major cations and anions $\left(\mathrm{Na}^{+}, \mathrm{Ca}^{++}, \mathrm{Cl}^{-}\right.$, bicarbonate, sulfate, etc.)

\section{RECENT LLNL PUBLICATIONS RELATED TO THIS PROJECT}

Singleton, M.J. and Moran, J.E. (2010) Dissolved noble gas and isotopic tracers reveal vulnerability of groundwater in a small, high elevation catchment to predicted climate changes. Water Resources Research doi: 10.1029/2009WR008718.

Singleton M. J., Moran J. E., Esser B. K., Hatch C. E., Tyler S. W., and Cox C. (2009) Mixed groundwater ages in a small alpine catchment (abstr). American Geophysical Union 2009 Fall Meeting (San Francisco; December 14-18, 2009); EOS Trans. 90(52), AGU Fall Meeting Suppl., Abstract H21G-08.

\section{STAFF}

\section{Dr. Michael J. Singleton, Task Lead}

Lawrence Livermore National Laboratory L-231, LLNL, Livermore, CA 94550

925/424-2022; singleton20@llnl.gov

Michael Singleton is a Staff Scientist in Lawrence Livermore National Laboratory's Chemical Sciences Division where he runs the Stable Isotope Mass Spectrometry Laboratory. Michael's research uses dissolved gas and stable isotope geochemistry to measure groundwater flow, determine groundwater vulnerability, and track contaminants through groundwater systems and the vadose zone. Current projects include determining residence times and recharge mechanisms in alpine groundwater systems, and developing new methods using stable isotope forensic signatures to track toxic substances. Michael holds a Ph.D. in Earth and Planetary Sciences from Washington University.

\section{Dr. Jean E. Moran, Assistant Professor}

California State University East Bay

Department of Earth and Environmental Sciences 
510/885-2491; jean.moran@csueastbay.edu

Dr. Jean Moran is on the faculty in the Department of Earth and Environmental Science at California State University, East Bay. Her research focuses on using natural and artificial isotopes to examine geochemical and transport processes in the vadose zone and in groundwater. Since 2001, she has carried out research on groundwater vulnerability, fate and transport of nitrate, and groundwater transport near artificial recharge areas under the Groundwater Ambient Monitoring and Assessment project sponsored by the California State Water Resources Control Board. Dr. Moran has a Ph.D. in Geochemistry from the University of Rochester, Bachelor's degrees in physics and geology from the University of Rochester and a Master's degree in geophysics from the University of Washington. She has been an author on more than 30 peer-reviewed publications and has been a Groundwater Resources Association of California Board Member since January, 2006.

\section{Dr. Bradley K. Esser; GAMA-LLNL Project Lead}

Lawrence Livermore National Laboratory

925/422-5247; bkesser@llnl.gov

Brad Esser is a staff scientist at Lawrence Livermore National Laboratory, where he is group leader for Environmental Radiochemistry and the lead for the LLNL Environmental Monitoring Radioanalytical Laboratory. He also leads LLNL's effort in the State of California Groundwater Ambient Monitoring \& Assessment (GAMA) program. Brad has a B.S. in Geosciences from the University of Arizona and a Ph.D. in Geochemistry from Yale University. His research interests include the use of groundwater age-dating, isotope biogeochemistry, and reactive transport modeling to develop better tools for water resource management, especially with regards to groundwater nitrate.

\section{Ate Visser, Postdoctoral Researcher}

Lawrence Livermore National Laboratory

925/423-0956; visser3@llnl.gov

Dr. Ate Visser is a postdoctoral researcher at Lawrence Livermore National Laboratory since August 2010. His research focuses on transport and travel times in groundwater. His research is part of the Groundwater Ambient Monitoring and Assessment (GAMA) project sponsored by the California State Water Resources Control Board. For the GAMA project, he is studying the groundwater quality of "old" groundwater in the State of California, as well as developing a mobile membrane inlet mass spectrometer (MIMS) for noble gases. The purpose of the noble gas MIMS is 
to trace the movement of water from an artificial recharge pond to its arrival at a drinking water production well.

In 2009, he received his PhD from Utrecht University, The Netherlands, for his thesis "Trends in groundwater quality in relation to groundwater age". He did his PhD work in collaboration with, and was subsequently employed by, Deltares, an independent institute for delta research in The Netherlands. 


\section{Appendix: Additional information on selected environmental tracers}

Dissolved noble gases: Dissolved gases are ideal tracers for examining recharge and transport of groundwater, especially in alpine systems where the fundamental parameters that govern gas solubility vary over short distances. The solubilities of the noble gases in fresh water vary as a function of temperature and pressure and are well known from theoretical and empirical studies (Error! Reference source not found., Andrews, 1991). Atmospheric, cosmogenic and anthropogenic radioactive gas species likewise are dissolved in infiltrating water according to Henry's Law. Once isolated from the atmosphere, inert dissolved gas species are transported conservatively in groundwater. The extremely low abundances of several dissolved gases in groundwater require ultra-sensitive mass spectrometry or counting techniques for detection.

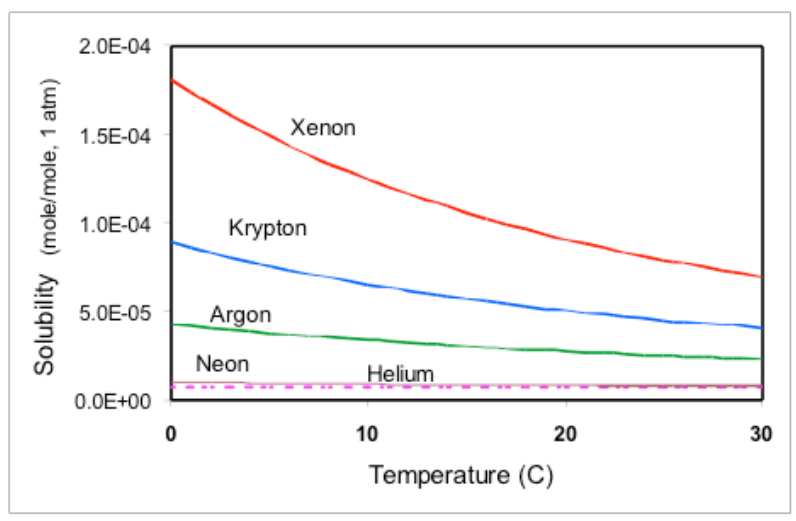

\section{Figure 1. Solubility of noble gases as a function of temperature.}

A robust estimate of the temperature at which recharge took place is determined by measuring the concentrations of all of the dissolved noble gases, and comparing the results to the solubility curves after correcting for the 'excess air' component. The temperature determination is weighted by the dissolved xenon concentration since it is most strongly dependent upon temperature. Under natural conditions, the temperature of recharge is strongly dependent upon the altitude of recharge, and noble gas recharge temperatures have been used successfully to determine recharge elevation in mountainous regions (Manning and Solomon, 2003).

The concentration of dissolved noble gases in groundwater is virtually always greater than equilibrium solubility (Error! Reference source not found.). The portion of gas in excess of equilibrium solubility is termed 'excess air' because of its compositional similarity to air (AesbachHertig et al., 2000, Holocher et al., 2002). During transport through the vadose zone, infiltrating water may entrain or trap air bubbles that subsequently dissolve in groundwater. Air bubbles may 
also become trapped in groundwater during fluctuations in the water table. The concentration of excess air provides unique information about the recharge process, including the degree to which infiltrating water incorporates vadose zone gas. Excess air concentrations are derived from the measurement of excess Neon concentration because Neon can be assumed to derive solely from the atmosphere.

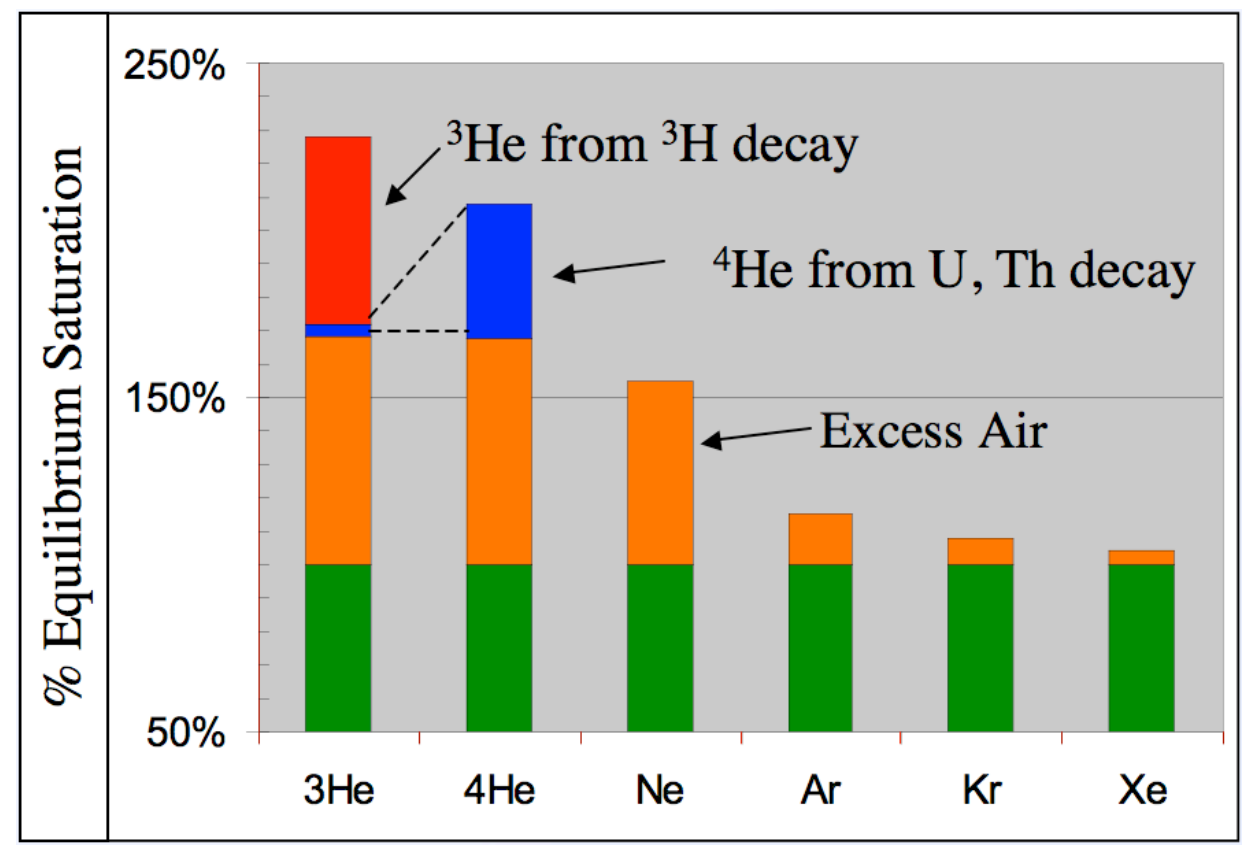

Figure 2. Concentrations of noble gases in a typical groundwater sample relative to equilibrium saturation. Dissolution of excess air, decay of $3 \mathrm{H}$, and incorporation of radiogenic gases from minerals add to the dissolved gas load.

Knowledge of excess air patterns in alpine aquifers is extremely limited. Preliminary studies by LLNL indicate that excess air concentrations are typically low in alpine settings. This is mostly likely due to a lower probability of air entrapment in fractured rock and the steady flow of recharge during snowmelt. Episodic changes in water levels have been shown to increase excess air concentrations (Hollocher et al., 2002). We hypothesize that a shift in climate that results in precipitation falling as episodic rain storms rather than a slow buildup and release of snow-water will cause an increase in excess air concentrations. Increased excess air concentrations in alpine aquifers over time are therefore a potential marker of climate change impacts.

Groundwater age dating: Complexity in aquifer systems typically results in mixing between waters recharged over a range of timescales. The mixing of different ages of water may obscure the true residence time of water in the aquifer. Measuring the groundwater age with one isotopic system gives a mean age for the fraction of groundwater recharged within the time span of that age tracer. However, by measuring groundwater age with multiple, overlapping isotopic age tracers it is possible to deconvolve the mixed age signal and determine the true residence time of 
groundwater in the Sierran aquifers. We will use ${ }^{3} \mathrm{H} /{ }^{3} \mathrm{He}$ and ${ }^{35} \mathrm{~S}$ dating techniques to provide a range of groundwater age-dating capabilities and to determine the mixing fractions of old and young groundwater in the system.

LLNL has a unique, high-throughput noble gas laboratory for application of the technique of tritium-helium groundwater age dating. Tritium $\left({ }^{3} \mathrm{H}\right)$ is a very low abundance (around 1 part in $10^{17}$ of total hydrogen), radioactive isotope of hydrogen with a half-life of 12.34 years. Atmospheric tritium enters groundwater as HTO during recharge. Its concentration in groundwater decreases by radioactive decay, dilution with non-tritiated groundwater, and dispersion. While the presence of tritium is an excellent indicator of water that recharged less than about 50 years ago, age dating groundwater using tritium alone results in large uncertainties due to spatial and temporal variation in the initial tritium at recharge. Measurement of both tritium and its daughter product helium-3 $\left({ }^{3} \mathrm{He}\right)$ allows calculation of the initial tritium present at the time of recharge, and ages can be determined from the following relationship:

$$
\text { Groundwater Age (years) }=-17.8 \times \ln \left(1+{ }^{3} \mathrm{He}_{\text {trit }} /{ }^{3} \mathrm{H}\right)
$$

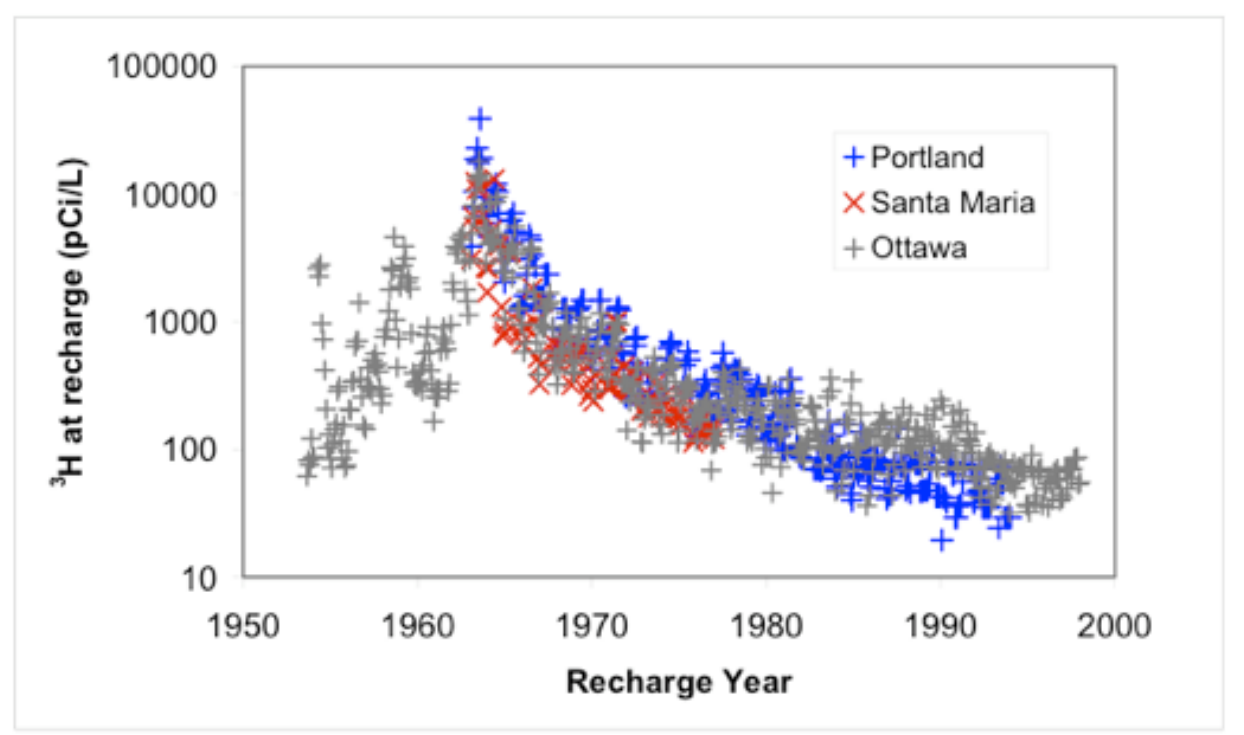

Figure 3. Tritium concentrations measured in precipitation at three North American
locations. Nuclear weapons testing introduced a large amount of tritium into the
atmosphere in the 1960 's, peaking in 1963 .

Sulfur-35 is a naturally occurring radioactive isotope of sulfur with a half-life 87.4 days (Friedlander et al., 1981)). It is produced in the upper atmosphere by cosmic rays via spallation reactions with ${ }^{40} \mathrm{Ar}$. After production, ${ }^{35} \mathrm{~S}$ rapidly oxidizes to $\mathrm{SO}_{2}$ and eventually to $\mathrm{SO}_{4}$ (sulfate). It is deposited to the earth's surface via wet and dry deposition (Tanaka and Turekian, 1991; Tanaka and Turekian, 1995) and enters the hydrologic cycle primarily as dissolved $\mathrm{SO}_{4}$. In addition to atmospheric deposition, a number of different reservoirs, which include the soil zone, minerals (primarily gypsum), and biota, contribute $\mathrm{SO}_{4}$ to groundwater and rivers. Because the activity of ${ }^{35} \mathrm{~S}$ 
approaches zero after about 5 half-lives (1.2 years), and the mean residence time of $\mathrm{SO}_{4}$ in these other reservoirs is relatively long ( $>1$ year), continental sources are ${ }^{35} \mathrm{~S}$-dead and dilute the atmospheric signal. Sulfur-35 has proved to be an ideal tracer for examining the mean residence time of $\mathrm{SO}_{4}$ and groundwater in alpine watersheds where groundwater residences times may be very short, where biogeochemical cycling and water/rock interactions are minimal, and where the hydrologic sulfate budget is dominated by atmospheric inputs (Cooper et al., 1991; Michel et al., 2000; Shanley et al., 2005; Sueker et al., 1999). These ${ }^{35}$ S studies have shown that sulfate exported from alpine basins has a mean age of a few hundred days (Sueker et al., 1999; Michel et al., 2000). When sulfate response in a basin is conservative, the age of water may be assumed to be that of the dissolved sulfate in it. In one study contrasting three high-altitude basins in Colorado (Sueker et al., 1999), the age of sulfate (and presumably water) was about 200 days in two steep, glaciated basins with steep topography and about 400 days in one basin with gentle topography and extensive debris cover. The 200-day difference in mean age was attributed to storage of water (and sulfate) in surficial debris. For the current study, ${ }^{35} \mathrm{~S}$, with its three month half-life, will be an ideal isotope for determining the fraction of groundwater recharged during the previous winter. Knowing the fraction of baseflow supported by the current year's precipitation will greatly improve our understanding of the size and retention time of Sierra Nevada alpine groundwater basins.

Stable isotopes of water: The minor stable isotopes, ${ }^{2} \mathrm{H}$ and ${ }^{18} \mathrm{O}$, of the water molecule vary in precipitation as a function of temperature, elevation and latitude (Craig, 1961; Ingraham \& Taylor, 1991). In California, extreme changes in elevation occur over relatively short distances, resulting in large variations in the oxygen and hydrogen isotopic compositions of water. The net effect of isotopic fractionation during evaporation and condensation is that surface water from mountain watersheds has a significantly lower abundance of ${ }^{18} \mathrm{O}$ and ${ }^{2} \mathrm{H}$ than coastal water (Error! Reference source not found.). The abundance of these isotopes in groundwater samples provides a fingerprint of the origin and elevation of the source water.

Results for stable isotope compositions are reported in "delta" units (e.g., $\delta^{18} 0$ ), the commonly used convention, where the samples isotope ratio (e.g., ${ }^{180} /{ }^{160}$ ) is normalized to the ratio of a common standard reference material (Standard Mean Ocean Water (SMOW) for water). The delta values are given in per mil (parts per thousand; $10 \% 0=1 \%$ ).

$$
\delta^{18} O=\left[\frac{\left(\frac{{ }^{18} O}{{ }^{16} O}\right)_{\text {sample }}}{\left(\frac{{ }^{18} O}{\left({ }^{16} O\right.}\right)_{\text {SMOW }}}-1\right] \times 1000
$$




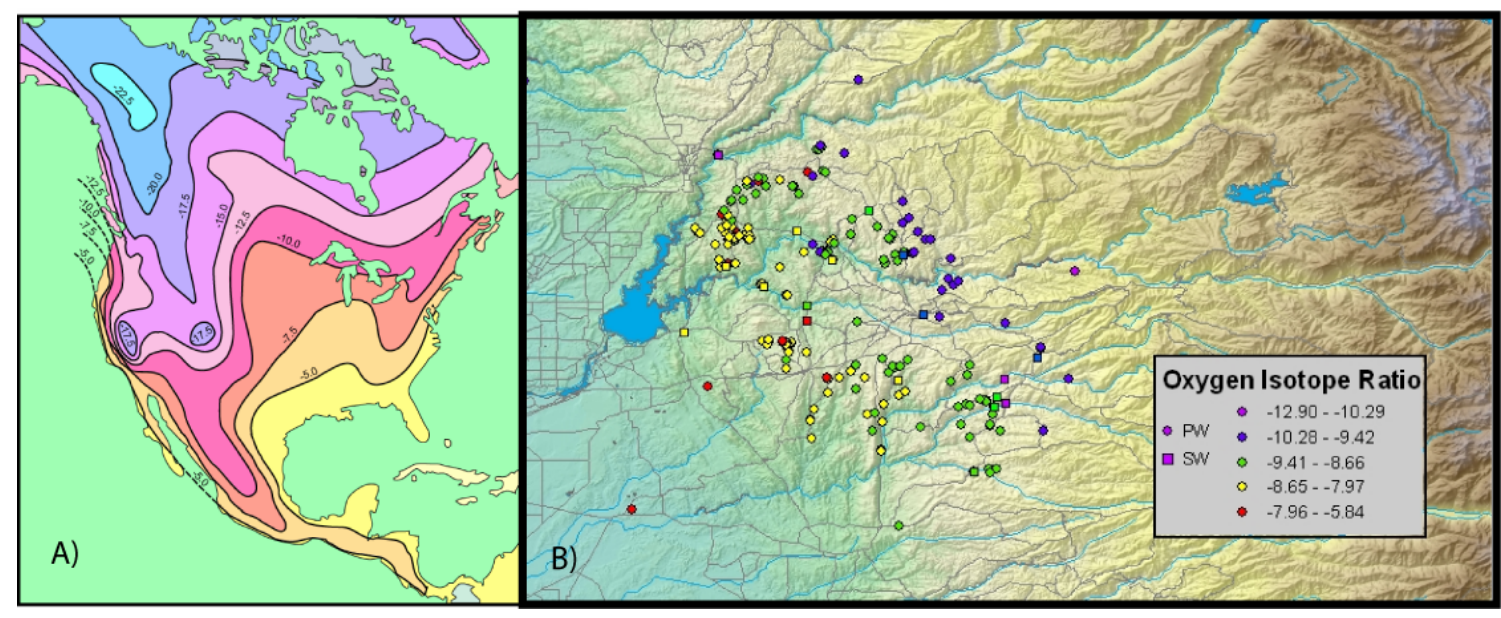

Figure 4. Contour map of oxygen isotope values $\left(\delta^{18} \mathrm{O}\right.$ SMOW) in precipitation $(\mathrm{A})$ and groundwater (individual wells shown by filled circles) in the Sierra foothills (B) showing tight contours and lighter, depleted values at high elevation in California. (A. After Taylor, 1974; B. from LLNL-GAMA project data).

Stable isotope composition of dissolved inorganic carbon (DIC) is an indicator of recharge source areas and processes. The stable isotopic composition $\left({ }^{13} \mathrm{C} /{ }^{12} \mathrm{C}\right)$ of DIC in groundwater that recharges through soil where active plant root respiration occurs will inherit a depleted carbon isotope signature. In contrast, waters that recharge through bare fractured rock, or from streams, will carry a carbon isotope signature that is in equilibrium with atmospheric $\mathrm{CO}_{2}$.

General groundwater chemistry concentrations (e.g., $\mathrm{Ca} 2+, \mathrm{Na}+, \mathrm{Cl}-, \mathrm{SO} 4-$, etc) provide a starting point for linking ground and surface water geochemistry with the focus of determining the age of baseflow (Rademacher et al., 2005). A study conducted in a small high elevation Sierran watershed, Sagehen basin, demonstrated that Sierran groundwater chemically evolves and can have residence time of years to decades (Rademacher et al., 2001).

\section{ADDITIONAL REFERENCES}

Aeschbach-Hertig, W., F. Peeters, U. Beyerle \& R. Kipfer, 2000. Palaeotemperature reconstruction from noble gases in ground water taking into account equilibration with entrapped air. Nature 405: 1040-1044.

Andrews, J.N., 1991, Noble gases and radioelements in groundwater. In: R.A. Downing and W.B. Wilkinson, Editors, Applied Groundwater Hydrology, Oxford University Press (1991), pp. 243-265 Ch. 15. 
Blumhagen, E.D. and J.F. Clark, 2008, Carbon sources and signals through time in an Alpine groundwater Basin, Sagehen California, Applied Geochemistry, 23, 2284-2291.

Burns, D. A, P. S. Murdoch, G. B. Lawrence, and R. L. Michel, 1998. Effect of groundwater springs on $\mathrm{NO}_{3}$ concentrations during summer in Catskill Mountain streams. Water Resour. Res., 34, 1987-1996.

Cooper, L. W., C. R. Olsen, D. K. Solomon, I. L. Larsen, R. B. Cook, and J. M. Grebmeier, 1991. Stable isotopes of oxygen and natural and fallout radionuclides used for tracing runoff during snowmelt in an artic watershed. Water Resour. Res., 27, 2171-2179.

Craig, H. 1961 Isotopic variations in meteoric waters. Science, v. 133, p. 1702-1703.

Dettinger, M. D. and D. R. Cayan (1994) Large-scale atmospheric forcing of receant trends towards early snowmelt runoff in California. Journal of Climate, 8, 606-622.

Friedlander, G., Kennedy, J. W., and Macias, E. S., 1981. Nuclear and Radiochemistry. John Wiley \& Sons, New York.

Ingraham, N.L., and Taylor, B.E. (1991) Light stable isotope systematics of large-scale hydrologic regimes in California and Nevada. Water Resources Research, v. 27, n. 1, p. 77-90.

Manning AH. Solomon DK. 2003. Using noble gases to investigate mountain-front recharge. Journal of Hydrology. 275(3-4):194-207.

Michel, R. L., D. Campbell, D. Clow, and J. T. Turk, 2000. Timescales for migration of atmospherically derived sulphate through an alpine/subalpine watershed, Loch Vale, Colorado. Water Resour. Res., 36, 27-36.

Rademacher, L. K., J. F. Clark, G. B. Hudson, D. C. Erman, and N. A. Erman (2001) Chemical evolution of shallow groundwater as recorded by springs, Sagehen basin, Nevada County California. Chemical Geology, 179, 37-51.

Rademacher, L. K., J. F. Clark, D. W. Clow, G. B. Hudson (2005) Old groundwater influence on stream hydrochemistry and catchment response in a small Sierra Nevada catchment: Sagehen Creek, California. Water Resources Research, 41, W02004, doi:10.1029/2003WR002805.

Shanley J. B., Mayer B., Mitchell M. J., Michel R. L., Bailey S. W., and Kendall C. (2005) Tracing sources of streamwater sulfate during snowmelt using $S$ and $O$ isotope ratios of sulfate and S-35 activity. Biogeochemistry 76(1), 161-185. 
Sueker, J. K., Turk, J. T., and Michel, R. L., 1999. Use of cosmogenic S-35 for comparing ages of water from three alpine-subalpine basins in the Colorado Front Range. Geomorphology 27, 61-74.

Tanaka, N. and Turekian, K. K., 1991. Use of cosmogenic S-35 to determine the rates of removal of atmospheric SO2. Nature 352, 226-228.

Tanaka, N. and Turekian, K. K., 1995. Determination of the dry deposition flux of SO2 using cosmogenic S-35 and Be-7 measurements. J. Geophys. Res.-Atmos. 100, 2841-2848Holocher J. Peeters F. Aeschbach-Hertig W. Hofer M. Brennwald M. Kinzelbach W. Kipfer R., 2002. Experimental investigations on the formation of excess air in quasi-saturated porous media. Geochimica et Cosmochimica Acta. 66(23):4103-4117. 